\title{
EVALUATION OF MIXTURES OF YELLOW LUPINE (LUPINUS LUTEUS L.) WITH SPRING CEREALS GROWN FOR SEEDS
}

\author{
KSIĘŻAK, J. - STANIAK, M.* - BOJARSZCZUK, J. \\ Department of Forage Crop Production, Institute of Soil Science and Plant Cultivation - State \\ Research Institute, Czartoryskich 8, 24-100 Puławy, Poland \\ (phone: +48-81-478-6790; fax: +48-81-478-6900) \\ *Corresponding author \\ e-mail: staniakm@iung.pulawy.pl \\ (Received $27^{\text {th }}$ Sep 2017; accepted $27^{\text {th }}$ Feb 2018)
}

\begin{abstract}
Cultivation of legume-cereals mixtures is considered a good agricultural practice in many European countries, especially in organic and low-input farming systems. The aim of the study was to determine the productivity of mixtures of yellow lupine (Lupinus luteus L.) with spring cereals, depending on the species of grain component and its percentage in mixture. Field experiments were carried out in the years of 2011-2013 at the Agricultural Experimental Station Grabów in Poland, using the system of random subblocks, with a control treatment, in four replications. The study included three species of cereals: wheat (Tricicum aestivum L.), barley (Hordeum vulgare L.), and triticale (Triticosecale Wittm. ex A. Camus), as well as three percentages of lupine in the weight of sown seeds: $40,60,80 \%$. The experiment was conducted on the soil of good wheat complex, class IIIa. The studies showed that the highest yield was obtained from the mixture of yellow lupine with wheat. Increasing the percentage of lupine seeds resulted in lower mixture yields, regardless of cereal species. Lupine grown in mixtures with cereals formed less pods, seeds per pod and per plant and produced a lower seed weight compared with their counterparts grown in pure stands. Legumes grown in mixture with cereals favorably affected morphological characteristics of cereals, contributing to their higher tillering and producing a higher number of grains per plant. The grain of cereals grown in mixtures with lupine had higher contents of total protein and crude fibre than the grain of cereals grown in pure stands.
\end{abstract}

Keywords: legume, share of components, yield, structure of yield, chemical composition

\section{Introduction}

Growing legume-cereal mixtures for grain is one of the ways of obtaining concentrated feed both in organic and in integrated production systems (Watson et al., 2002). Such sowings allow for a rational use of environmental resources, positively affect soil environment and provide a strong competition for weeds (Tofinga and Snaydon, 1992; Cremer et al., 1996; Büyükburç and Karadağ, 2002; Hauggaard-Nielsen and Jensen, 2004; Lithourgidis et al., 2006; Hauggaard-Nielsen et al., 2008; Corre-Hellou et al., 2011). Yielding and crop quality of legume-cereal mixtures largely depends on the selection of components and their participation. Generally, yield of mixture seeds decreases with increasing percentage of legumes at sowing, but interspecies interactions are largely determined by the characteristics of the components, which may, change during plant growth under the influence of variable habitat factors (Rudnicki and Kotwica, 2006). Cultivation of mixed crops increases the content of crude protein in the yield of the seeds mixture, but it is also related to selection and participation of the individual components (Staniak et al., 2014). Creating favorable conditions for cereals and legumes in mixture stands and reducing a competition between them during the period of vegetation are important agri-ecological and agri-technological issues. 
Species grown in mixed crops should have similar soil and climatic requirements, a similar maturation date and a similar height. A good component for mixtures with spring cereals is yellow lupine, which is characterized by a high protein content (over 40\%) rich in lysine and crude fat (over 50\%), which significantly increases the nutritional value of feed from such mixtures. In addition, it has low water and soil requirements thanks to a well-developed root system. According to Rudnicki and Kotwica (2006), on light soils, yellow lupine is a much better component for mixtures than blue lupine. The level of mixtures yielding and the share of seeds of individual components in the yield, and thus the value of fodder, depends not only on the selection of species, but also on their share in sown mixture.

The aim of the study was to determine the productivity and quality of mixtures of yellow lupine (Lupinus luteus L.) with spring cereals, depending on the species of grain component and its percentage in the weight of sown seeds.

\section{Review of literature}

Mixtures of spring cereals with legumes are considered good agricultural practice, especially in organic and low-input farming system (Hassen et al., 2017). Cultivation of mixtures contributes to the complementary use of habitat resources and compensatory growth of individual plant species, causing an increased productivity and greater stability of yield (Niggli et al., 2008; Doré et al., 2011). Cereals sown with legumes are a strong competitor to the legume which causes that the share of legume seeds in the mixture yield is often variable and low. Increasing the percentage of legume seeds in the sowing norm increases their share in the yield, but the yield of grain cereals and the total yield of mixtures generally decreases (Rudnicki and Wenda-Piesik, 2007). The competitiveness of the plants in legume-cereals mixtures for the access to environmental resources intensifies in the conditions of reduced soil moisture (Gałęzewski, 2006). Under these conditions, many authors observed increased fallout of lupine plants from the stand. Also, these plants formed a low number of pods, which resulted in low legume yields (Kotwica and Rudnicki, 2003).

The yield and stability of the mixtures are therefore determined by the cereals, and to a lower extent - by legumes, but when determining the quality of the mixtures, the share of legume seeds in the mixture yield is crucial. One of the most important criteria for grain quality evaluation is concentration of crude protein. The seeds of legumes are significantly different from the grains of cereals. They contain large amounts of total protein and crude fibre and considerably higher amount of minerals compared to the cereals (Johnston et al., 1978; Staniak et al., 2012). According to Księżak and Staniak (2013) increasing the share of blue lupine in two-species mixtures with barley, wheat and triticale resulted in an increase in the total protein content in the yield of mixtures seeds, and the concentration of crude fibre and crude fat has been also increased. The same relationships have been found in the studies on mixtures of wheat and spring barley with peas (Pozdísek et al., 2011).

\section{Materials and methods}

\section{Location of the experiment}

Field experiments with the mixtures of yellow lupine (Lupinus luteus L.) with spring cereals were carried out in the years of 2011-2013 at the Agricultural Experimental Station 
Grabów [51 $21^{\prime} 18^{\prime \prime} \mathrm{N} 21^{\circ} 40^{\prime} 09^{\prime \prime} \mathrm{E}$ ] in Poland, using the system of random sub-blocks, with a control treatment, in four replications. The plot size for the harvest was $27.0 \mathrm{~m}^{2}$. The experiment was conducted on the silty soil developed on the light loam, good wheat complex, class IIIa. The content ( $\left.\mathrm{mg} \mathrm{kg}^{-1}\right)$ of available phosphorus was from 13.3 to 16.0, potassium - from 8.1 to 8.4 , magnesium - from 3.9 to 4.1 , while $\mathrm{pH}$ was close to neutral (6.4-6.6).

\section{Plant materials}

The first factor was a species of spring cereals: wheat (Tricicum aestivum L.), barley (Hordeum vulgare L.), triticale (Triticosecale Wittm. ex A. Camus), and the secondary factor was the percentage of yellow lupine in the sown mixture: 40, 60 and 80\%. The density of components in pure sowing for which the density of plants in the mixtures was calculated was: lupine (variety Mister) -100 plants $\cdot \mathrm{m}^{-2}$, barley (variety Skarb) - 300 plants $\cdot \mathrm{m}^{-2}$, wheat (variety Bamberka) and triticale (variety Nagano) 500 plants $\mathrm{m}^{-2}$.

\section{Agrotechniques}

Winter plowing was carried out to a depth of $25 \mathrm{~cm}$, in the spring a cultivator and passive agricultural set (drag, spring-tine harrow, land roller) was used. The following mineral fertilizer doses were used $\left(\mathrm{kg} \cdot \mathrm{ha}^{-1}\right)$ : $\mathrm{P}-19.6, \mathrm{~K}-45.6$ and $\mathrm{N}-40$. The sowing was carried out from 11 to 23 April with the usage of Amazone grain drill. Before the sowing, the seeds were treated with a seed dressing Funaben T. Basagran $1.25 \mathrm{dm}^{3} \cdot \mathrm{ha}^{-1}$ or Stomp $330 \mathrm{EC}$ at a dose of $3.5 \mathrm{dm}^{3} \cdot \mathrm{ha}^{-1}$; it was used to remove weeds from the mixture. Harvest of mixtures was carried out in the period from 8 to 23 August with the usage of Sedmaster plot harvester.

\section{Measurement and testing methods}

Before the harvest, a number of pods and seeds per pod, and a number and weight of seeds per plant were determined in 10 randomly selected plants of lupine per each subplot. While in cereals, a number and weight of grains per plant, a number of grains per ear, the height of culms and a number of productive culms were specified. After the harvest, the seed yield of lupine-cereal mixture and thousand seed weight of its components were determined. The percentage of seeds of both species in the mixture was marked after the separation of the yield from the entire plot. The contents of total protein and crude fibre in cereal grains and yellow lupine seeds were also determined.

The impact of the examined experimental factors on the determined characteristics were assessed using the analysis of variance, the half-intervals of confidence being determined by Tukey's test at the significance level of $\alpha=0.05$. The results were statistical analysis of variance using Statistica v.10.0 program.

\section{Results and discussion}

Weather conditions had a significant impact on the yield of cereals and yellow lupine in pure stands, while the yield of mixtures additionally depended on the selection and percentage of the components. The highest seed yields, especially of yellow lupine, were obtained in 2013, when the sum of precipitation during the period from April to August amounted to about $400 \mathrm{~mm}$. There was a favorable distribution of rainfall in 
June, a small amount of precipitation in July and August and the largest relative air humidity during flowering of plants (Table 1). That year also saw a slightly higher average air temperature during the growing season, compared with the mean from a multi-year period. In 2012, a small amount of rainfall in the third decade of June and the first decade of July caused strong inhibition of the growth and development of yellow lupine, and consequently, a very low yield of seeds. Rojek (1989) pointed out large water requirements and sensitivity of yellow lupine, especially in the period from flowering until the end of pod formation. Gałęzewski (2006) stated that competition for water of lupine and oats is stronger when they are grown in mixtures compared to pure stands. According to Podleśny and Podleśna (2010) mixtures of blue lupine with barley are less sensitive to droughts than lupine grown in pure stands. Also Księżak and Magnuszewska (1999) confirmed that under reduced soil moisture, growing legumecereal mixtures provides a greater stability and higher level of yielding than the cultivation of these plants in pure stands. In 2011, with not very favorable weather conditions, the obtained seed yields were by about $25 \%$ lower compared to the yields of 2013. July and early August of that year saw a large amount of precipitation, which caused the strong lodging of plants, extended the period of plant maturing, impeded harvesting and caused higher seed shedding.

Table 1. Course of weather conditions during the vegetation periods

\begin{tabular}{c|c|c|c|c|c|c|c|c}
\hline \multirow{2}{*}{ Months } & \multicolumn{3}{|c|}{ Mean monthly of temperature $\left({ }^{\circ} \mathbf{C}\right)$} & \multicolumn{3}{|c}{ Sum of monthly precipitation (mm) } \\
\cline { 2 - 9 } & $\mathbf{2 0 1 1}$ & $\mathbf{2 0 1 2}$ & $\mathbf{2 0 1 3}$ & $\begin{array}{r}\text { Average of } \\
\text { multi-year } \\
\text { period }\end{array}$ & $\mathbf{2 0 1 1}$ & $\mathbf{2 0 1 2}$ & $\mathbf{2 0 1 3}$ & $\begin{array}{c}\text { Average of } \\
\text { multi-year } \\
\text { period }\end{array}$ \\
\hline April & 10.3 & 9.6 & 8.3 & 7.7 & 35.9 & 37.8 & 29.9 & 39 \\
May & 13.9 & 15.3 & 15.3 & 13.4 & 74.5 & 36.5 & 112 & 57 \\
June & 18.5 & 17.7 & 18.6 & 16.7 & 52.4 & 54.3 & 116.3 & 71 \\
July & 18.4 & 20.9 & 19.7 & 18.3 & 298.8 & 81.6 & 20.8 & 84 \\
August & 18.8 & 18.8 & 19.2 & 17.3 & 35.6 & 64.2 & 11.6 & 75 \\
\hline
\end{tabular}

The yields of cereals grown in pure stands were similar and significantly higher than the yields of lupine grown in pure stands (Table 2). Among the studied mixtures, the highest seed yields were obtained from stands of lupine with wheat compared with mixtures with barley and triticale; they were higher by approximately 10 and $7 \%$ (average for three years) (Table 3). The yield of spring cereals mixed with yellow lupine, especially with the $80 \%$ share of this species, was generally lower than the yield of cereals grown in pure stands. Rudnicki and Gałęzewski (2007b) showed that the yields of oats-yellow lupine mixtures were lower than the yields of oats in pure stands, and that they depended mainly on the yield of oats. Different results were presented by Rudnicki and Kotwica (2006), who recorded higher yields of spring cereals mixed with lupines (yellow and blue) compared with the yields of these components in pure sowings. These authors also indicated that yellow lupine was a more favorable component for mixtures with these cereals than blue lupine. 
Table 2. Seeds yield of yellow lupine and spring cereals grown in pure sowing $\left(t \cdot h a^{-1}\right)$

\begin{tabular}{c|c|c|c|c}
\hline Cereal species & $\mathbf{2 0 1 1}$ & $\mathbf{2 0 1 2}$ & $\mathbf{2 0 1 3}$ & Mean \\
\hline Barley & $3.18 \mathrm{~b}^{*}$ & $3.59 \mathrm{bc}$ & $4.18 \mathrm{~b}$ & 3.61 \\
Wheat & $3.29 \mathrm{~b}$ & $3.40 \mathrm{~b}$ & $4.44 \mathrm{c}$ & 3.71 \\
Triticale & $3.36 \mathrm{~b}$ & $3.72 \mathrm{c}$ & $4.13 \mathrm{~b}$ & 3.73 \\
Lupine & $1.56 \mathrm{a}$ & $0.90 \mathrm{a}$ & $2.20 \mathrm{a}$ & 1.55 \\
\hline
\end{tabular}

$*$ Values in the same column followed by a different letter are significantly different $(\mathrm{p}<0.05)$

Table 3. Seeds yield of yellow lupine-cereal mixtures depending on cereal species and percentage of lupine $\left(t \cdot h a^{-1}\right)$

\begin{tabular}{c|c|c|c|c}
\hline \multirow{2}{*}{ Years } & $\begin{array}{c}\text { Lupine } \\
\text { percentage }(\boldsymbol{\%})\end{array}$ & Barley & Wheat & Triticale \\
\hline \multirow{3}{*}{2011} & 40 & $2.95 \mathrm{~b}^{*}$ & $3.58 \mathrm{c}$ & $3.14 \mathrm{c}$ \\
& 60 & $2.94 \mathrm{~b}$ & $3.33 \mathrm{~b}$ & $2.93 \mathrm{~b}$ \\
& 80 & $2.24 \mathrm{a}$ & $3.17 \mathrm{a}$ & $2.64 \mathrm{a}$ \\
\cline { 2 - 5 } & Mean & 2.71 & 3.36 & 2.90 \\
\hline \multirow{3}{*}{2012} & 40 & $3.33 \mathrm{c}$ & $3.92 \mathrm{c}$ & $3.30 \mathrm{~b}$ \\
& 60 & $3.12 \mathrm{~b}$ & $3.42 \mathrm{~b}$ & $3.13 \mathrm{~b}$ \\
& 80 & $2.65 \mathrm{a}$ & $3.00 \mathrm{a}$ & $2.94 \mathrm{a}$ \\
\cline { 2 - 5 } & Mean & 3.03 & 3.45 & 3.12 \\
\hline \multirow{3}{*}{2013} & 40 & $4.03 \mathrm{c}$ & $3.99 \mathrm{c}$ & $4.06 \mathrm{c}$ \\
& 60 & $3.78 \mathrm{~b}$ & $3.67 \mathrm{~b}$ & $3.64 \mathrm{~b}$ \\
& 80 & $3.37 \mathrm{a}$ & $3.32 \mathrm{a}$ & $3.41 \mathrm{a}$ \\
\cline { 2 - 5 } & Mean & 3.73 & 3.66 & 3.70 \\
\hline
\end{tabular}

$*$ Values in the same column followed by a different letter are significantly different $(\mathrm{p}<0.05)$

The seeds yield of yellow lupine and its percentage in mixtures with cereals varied depending on weather conditions during the growing season, a species of cereal component in the mixture, and its percentage in the weight of sown seeds. The seeds yield of legumes in the mixtures with any cereal in the first and second year of the experiment was significantly lower compared to pure stands (on average by $50 \%$ in the first and $41 \%$ in the second year), while in the third year, it was higher only in mixtures with wheat (by about 36\%) (Table 4). Increasing the percentage of lupine in the weight of sown seeds caused an increase in its percentage in the mixture yield, but only in the third year, with favorable moisture conditions. Its percentage in the yield was similar to the number of sown seeds. In the studies of Rudnicki and Gałęzewski (2007a), the yield of lupine seeds in mixtures with cereals was several times lower than in pure stands. At the same time, it significantly varied during individual years of the study. Increasing the sowing rate of lupine seeds in the mixtures caused an increase in the percentage of its seeds in mixture yield, but at the same time, this percentage was negatively correlated with the mixture yield. According to numerous authors, legume-cereal mixtures yield best when legume seeds constitute from 30 to $50 \%$ of seeds at the sowing (Jaranowski, 1997; Szczukowski, 1989). Księżak (2006) obtained significantly higher yields of mixtures of peas with spring wheat at $30 \%$ share of legume seeds at sowing. The yields 
decreased together with increasing the percentage of peas up to 40 and 50\%. Księżak and Magnuszewska (1999) however, did not record any effect of increasing the percentage of pea at sowing on the seed yield of pea-wheat mixtures grown conventionally. According to the literature data, triticale is the least competitive spring cereal against lupine (Kotwica and Rudnicki, 2003, 2004).

Table 4. Yield of lupine seeds and percentage of lupine seeds in yield of mixtures with cereals depending on cereal species and percentage of lupine

\begin{tabular}{|c|c|c|c|c|c|c|c|}
\hline \multirow{2}{*}{ Years } & \multirow{2}{*}{$\begin{array}{c}\text { Lupine } \\
\text { percentage } \\
(\%)\end{array}$} & \multicolumn{3}{|c|}{ Yield of lupine seeds $\left(t \cdot h^{-1}\right)$} & \multicolumn{3}{|c|}{ Percentage of lupine seeds (\%) } \\
\hline & & Barley & Wheat & Triticale & Barley & Wheat & Triticale \\
\hline \multirow{4}{*}{2011} & 40 & $0.49 \mathrm{a}^{*}$ & $0.67 \mathrm{a}$ & $0.57 \mathrm{a}$ & 16.6 & 18.5 & 17.5 \\
\hline & 60 & $0.75 \mathrm{~b}$ & $0.84 \mathrm{~b}$ & $0.84 \mathrm{~b}$ & 24.9 & 25.0 & 26.7 \\
\hline & 80 & $0.76 \mathrm{~b}$ & $1.13 \mathrm{c}$ & $0.93 \mathrm{c}$ & 32.1 & 34.3 & 33.4 \\
\hline & Mean & 0.67 & 0.88 & 0.78 & 24.5 & 25.9 & 25.9 \\
\hline \multirow{4}{*}{2012} & 40 & $0.10 \mathrm{a}$ & $0.13 \mathrm{a}$ & $0.11 \mathrm{a}$ & 3.0 & 3.2 & 3.2 \\
\hline & 60 & $0.21 \mathrm{~b}$ & $0.24 \mathrm{~b}$ & $0.22 \mathrm{~b}$ & 6.8 & 7.1 & 6.8 \\
\hline & 80 & $0.22 \mathrm{~b}$ & $0.29 \mathrm{~b}$ & $0.23 \mathrm{~b}$ & 8.2 & 9.6 & 9.4 \\
\hline & Mean & 0.18 & 0.22 & 0.19 & 6.0 & 6.6 & 6.5 \\
\hline \multirow{4}{*}{2013} & 40 & $1.57 \mathrm{a}$ & $2.81 \mathrm{a}$ & $1.66 \mathrm{a}$ & 39.3 & 70.5 & 40.9 \\
\hline & 60 & $1.84 \mathrm{~b}$ & $3.08 \mathrm{~b}$ & $1.69 \mathrm{a}$ & 49.4 & 83.8 & 46.1 \\
\hline & 80 & $1.93 \mathrm{~b}$ & $3.12 \mathrm{~b}$ & $2.09 \mathrm{~b}$ & 57.5 & 93.8 & 61.1 \\
\hline & Mean & 1.78 & 3.00 & 1.81 & 48.7 & 82.7 & 49.4 \\
\hline
\end{tabular}

*Values in the same column followed by a different letter are significantly different $(\mathrm{p}<0.05)$

The lowest number of pods per plant and seeds per pod, both in pure stands and in mixtures, was produced by lupine plants grown in 2012, while the highest - in 2013, the year with favorable weather conditions (Table 5). The most seeds per pods were set by lupine grown in the mixture with triticale, while the least - in the stand with wheat. A species of cereal had a relatively small effect on the number and weight of seeds per plant, although in all the years of the research, smaller values of these characteristics were recorded for lupine grown in a mixture with wheat compared to the stands with barley and triticale (Table 6). In the first two years of the experiment, lupine in mixtures set a lower number of pods and seeds, and produced a lower seed weight per plant than in pure stand. These values considerably increased in the third year of the study, regardless of the used cereal species. In 2011 and 2012, increasing the percentage of lupine in the mixture positively affected the number of pods, seeds, and seed weight per plant, while in the third year, there was a decrease in the number of pods. According to Rudnicki and Gałęzewski (2007a), all the features of yellow lupine in mixtures (except for height) were much less developed than in the cultivation in pure stands. Lupine grown in pure stand and in mixtures in 2013 had the highest weight of thousand seeds, regardless of the species of a cereal component of the mixture (Table 7). Moreover, lupine has larger seeds when grown in a mixture with triticale than the lupine grown with other cereal species. Increasing the percentage of lupine in the mixture with barley and wheat reduced the size of seeds, while triticale had a much lower influence on this feature. 
Table 5. Number of yellow lupine pods per plants and seeds per pod depending on cereal species and percentage of lupine in mixture

\begin{tabular}{|c|c|c|c|c|c|c|c|}
\hline Years & \begin{tabular}{|c|} 
Lupine percentage \\
$(\%)$
\end{tabular} & \multicolumn{3}{|c|}{$\begin{array}{c}\text { Number of pods per plants } \\
\text { (unit) }\end{array}$} & \multicolumn{3}{|c|}{$\begin{array}{c}\text { Number of seeds per pod } \\
\text { (unit) }\end{array}$} \\
\hline 2011 & 100 & \multicolumn{3}{|c|}{$5.15 \mathrm{~b}^{*}$} & \multicolumn{3}{|c|}{$3.67 \mathrm{~b}$} \\
\hline 2012 & 100 & \multicolumn{3}{|c|}{$1.74 \mathrm{a}$} & \multicolumn{3}{|c|}{$2.52 \mathrm{a}$} \\
\hline 2013 & 100 & \multicolumn{3}{|c|}{$6.37 \mathrm{~b}$} & \multicolumn{3}{|c|}{$3.53 \mathrm{~b}$} \\
\hline & & Barley & Wheat & Triticale & Barley & Wheat & Triticale \\
\hline \multirow{4}{*}{2011} & 40 & $2.90 \mathrm{a}$ & $1.17 \mathrm{a}$ & $2.45 \mathrm{a}$ & $2.84 \mathrm{a}$ & $2.24 \mathrm{a}$ & $3.14 \mathrm{a}$ \\
\hline & 60 & $3.20 \mathrm{~b}$ & $2.10 \mathrm{~b}$ & $2.45 \mathrm{a}$ & $2.85 \mathrm{a}$ & $2.22 \mathrm{a}$ & $3.18 \mathrm{a}$ \\
\hline & 80 & $3.65 \mathrm{c}$ & $3.10 \mathrm{c}$ & $2.55 \mathrm{a}$ & $3.12 \mathrm{~b}$ & $2.21 \mathrm{a}$ & $3.39 \mathrm{~b}$ \\
\hline & Mean & 3.25 & 2.12 & 2.48 & 2.94 & 2.22 & 3.24 \\
\hline \multirow{4}{*}{2012} & 40 & $0.53 \mathrm{a}$ & $0.48 \mathrm{a}$ & $0.66 \mathrm{a}$ & $2.19 \mathrm{a}$ & $2.14 \mathrm{a}$ & $2.15 \mathrm{a}$ \\
\hline & 60 & $0.62 \mathrm{a}$ & $0.66 \mathrm{~b}$ & $0.94 \mathrm{~b}$ & $2.26 \mathrm{a}$ & $2.10 \mathrm{a}$ & $2.50 \mathrm{~b}$ \\
\hline & 80 & $0.95 \mathrm{~b}$ & $0.87 \mathrm{c}$ & $1.04 \mathrm{~b}$ & $2.43 \mathrm{~b}$ & $2.33 \mathrm{~b}$ & $2.45 \mathrm{~b}$ \\
\hline & Mean & 0.70 & 0.67 & 0.88 & 2.29 & 2.19 & 2.37 \\
\hline \multirow{4}{*}{2013} & 40 & $8.17 \mathrm{c}$ & $8.83 \mathrm{c}$ & $7.96 \mathrm{c}$ & $3.66 \mathrm{a}$ & $3.70 \mathrm{~b}$ & $3.74 \mathrm{~b}$ \\
\hline & 60 & $7.30 \mathrm{~b}$ & $7.80 \mathrm{~b}$ & $7.27 \mathrm{~b}$ & $3.58 \mathrm{a}$ & $3.60 \mathrm{~b}$ & $3.57 \mathrm{a}$ \\
\hline & 80 & $6.40 \mathrm{a}$ & $7.30 \mathrm{a}$ & $7.17 \mathrm{a}$ & $3.71 \mathrm{~b}$ & $3.45 \mathrm{a}$ & $3.62 \mathrm{a}$ \\
\hline & Mean & 7.29 & 7.98 & 7.47 & 3.65 & 3.58 & 3.64 \\
\hline
\end{tabular}

*Values in the same column followed by a different letter are significantly different $(\mathrm{p}<0.05)$

Table 6. Number and weight of yellow lupine seeds on plant depending on cereal species and percentage of lupine in mixture

\begin{tabular}{|c|c|c|c|c|c|c|c|}
\hline Years & $\begin{array}{c}\text { Lupine } \\
\text { percentage }(\%)\end{array}$ & \multicolumn{3}{|c|}{ Number of seeds (unit) } & \multicolumn{3}{|c|}{ Weight of seeds (g) } \\
\hline 2011 & 100 & \multicolumn{3}{|c|}{$19.00 \mathrm{~b}^{*}$} & \multicolumn{3}{|c|}{$2.38 \mathrm{~b}$} \\
\hline 2012 & 100 & \multicolumn{3}{|c|}{$4.38 \mathrm{a}$} & \multicolumn{3}{|c|}{$0.53 \mathrm{a}$} \\
\hline 2013 & 100 & \multicolumn{3}{|c|}{$22.47 \mathrm{~b}$} & \multicolumn{3}{|c|}{$3.13 \mathrm{c}$} \\
\hline & & Barley & Wheat & Triticale & Barley & Wheat & Triticale \\
\hline \multirow{4}{*}{2011} & 40 & $8.20 \mathrm{a}$ & $2.50 \mathrm{a}$ & $7.70 \mathrm{a}$ & $0.98 \mathrm{a}$ & $0.30 \mathrm{a}$ & $0.89 \mathrm{a}$ \\
\hline & 60 & $9.21 \mathrm{a}$ & $4.80 \mathrm{~b}$ & $7.85 \mathrm{a}$ & $1.12 \mathrm{a}$ & $0.62 \mathrm{~b}$ & $0.94 \mathrm{a}$ \\
\hline & 80 & $11.55 \mathrm{~b}$ & $6.80 \mathrm{c}$ & $8.65 \mathrm{~b}$ & $1.32 \mathrm{~b}$ & $0.78 \mathrm{c}$ & $1.02 \mathrm{~b}$ \\
\hline & Mean & 9.65 & 4.70 & 8.06 & 1.14 & 0.57 & 0.95 \\
\hline \multirow{4}{*}{2012} & 40 & $1.16 \mathrm{a}$ & $1.03 \mathrm{a}$ & $1.43 \mathrm{a}$ & $0.14 \mathrm{a}$ & $0.12 \mathrm{a}$ & $0.18 \mathrm{a}$ \\
\hline & 60 & $1.40 \mathrm{a}$ & $1.39 \mathrm{a}$ & $2.35 \mathrm{~b}$ & $0.16 \mathrm{a}$ & $0.17 \mathrm{a}$ & $0.29 \mathrm{~b}$ \\
\hline & 80 & $2.31 \mathrm{~b}$ & $2.03 \mathrm{~b}$ & $2.56 \mathrm{~b}$ & $0.26 \mathrm{~b}$ & $0.25 \mathrm{~b}$ & $0.31 \mathrm{~b}$ \\
\hline & Mean & 1.62 & 1.48 & 2.11 & 0.19 & 0.18 & 0.26 \\
\hline \multirow{4}{*}{2013} & 40 & $29.83 \mathrm{c}$ & $32.60 \mathrm{c}$ & $29.70 \mathrm{~b}$ & $3.70 \mathrm{~b}$ & $3.94 \mathrm{c}$ & $3.70 \mathrm{~b}$ \\
\hline & 60 & $26.10 \mathrm{~b}$ & $28.03 \mathrm{~b}$ & $25.95 \mathrm{a}$ & $3.06 \mathrm{a}$ & $3.31 \mathrm{~b}$ & $3.24 \mathrm{a}$ \\
\hline & 80 & $23.73 \mathrm{a}$ & $25.17 \mathrm{a}$ & $25.96 \mathrm{a}$ & $2.88 \mathrm{a}$ & $2.44 \mathrm{a}$ & $3.37 \mathrm{a}$ \\
\hline & Mean & 26.55 & 28.60 & 27.20 & 3.21 & 3.23 & 3.44 \\
\hline
\end{tabular}

*Values in the same column followed by a different letter are significantly different $(\mathrm{p}<0.05)$ 
Table 7. Weight of thousand seeds of yellow lupine depending on cereal species and percentage of lupine in mixture

\begin{tabular}{l|c|c|c|c}
\hline \multirow{2}{*}{ Years } & $\begin{array}{c}\text { Lupine percentage } \\
(\%)\end{array}$ & \multicolumn{3}{|c}{ Weight of 1000 seeds (g) } \\
\hline 2011 & 100 & & 326.0 & \\
2012 & 100 & & 121.9 \\
2013 & 100 & Barley & Wheat & Triticale \\
\hline \multirow{3}{*}{2011} & 40 & $119.4 \mathrm{a}$ & $121.1 \mathrm{a}$ & $113.7 \mathrm{a}$ \\
& 60 & $118.9 \mathrm{a}$ & $122.9 \mathrm{a}$ & $114.4 \mathrm{a}$ \\
& 80 & $117.8 \mathrm{a}$ & $119.1 \mathrm{a}$ & $111.7 \mathrm{a}$ \\
\hline \multirow{3}{*}{2012} & Mean & 118.7 & 121.0 & 113.3 \\
\cline { 2 - 5 } & 40 & $117.5 \mathrm{~b}$ & $118.9 \mathrm{a}$ & $122.0 \mathrm{a}$ \\
& 60 & $114.4 \mathrm{a}$ & $121.4 \mathrm{~b}$ & $122.4 \mathrm{a}$ \\
& 80 & $113.4 \mathrm{a}$ & $125.0 \mathrm{c}$ & $122.3 \mathrm{a}$ \\
\cline { 2 - 5 } & Mean & 115.1 & 121.8 & 122.2 \\
\hline \multirow{3}{*}{2013} & 40 & $125.6 \mathrm{~b}$ & $122.8 \mathrm{a}$ & $127.4 \mathrm{a}$ \\
& 60 & $120.0 \mathrm{a}$ & $119.4 \mathrm{~b}$ & $125.2 \mathrm{a}$ \\
& 80 & $121.7 \mathrm{a}$ & $117.5 \mathrm{~b}$ & $130.1 \mathrm{~b}$ \\
\hline & Mean & 122.4 & 119.9 & 127.6 \\
\hline
\end{tabular}

*Values in the same column followed by a different letter are significantly different $(\mathrm{p}<0.05)$

Growing yellow lupine in mixtures with cereals, as well as increasing its percentage had a beneficial effect on the number and weight of grains per plant (Table 8). In all years of the study, the smallest seed weight in the mixtures was recorded for wheat, while significantly largest, for barley. All species of cereals, grown both in mixtures and in pure stands, produced the smallest weight and number of grains per plant in 2012. Cereals in mixtures tillered slightly better than those grown in pure stands, and the tillering of cereals was positively affected by increasing the percentage of lupine in sowing. Barley grown in mixtures formed a similar number of grains per ear as barley grown in pure stand, while wheat and triticale - slightly higher (Table 9). Both, weather during the growing season and the share of components in the mixture, had little impact on the development of this feature, as well as on the height of culms (Table 10). The percentage of lupine in the mixture also had a relatively small effect on the thousand grains weight of cereals. Only in 2011, wheat and triticale reacted positively to increasing the percentage of legumes in the mixture. According to Rudnicki and Gałęzewski (2007b), the reaction of oats to sowing in the mixture with lupine was relatively weak, and the composition of the mixture affected only productive tillering, and grain yielding of oats. Rudnicki and Kotwica (2007) reported that yellow lupine generally shows little competitive potential against oats, but increasing its percentage in the stand caused an increase in its competitive strength against that cereal. 
Table 8. Number and weight of cereals grain per plant depending on cereal species and percentage of lupine in mixture

\begin{tabular}{|c|c|c|c|c|c|c|c|}
\hline \multirow{2}{*}{ Years } & \multirow{2}{*}{$\begin{array}{c}\text { Lupine } \\
\text { percentage } \\
(\%)\end{array}$} & \multicolumn{3}{|c|}{ Weight of grain per plant (g) } & \multicolumn{3}{|c|}{ Number of grain per plant (unit) } \\
\hline & & Barley & Wheat & Triticale & Barley & Wheat & Triticale \\
\hline 2011 & 0 & $3.30 \mathrm{~b}^{*}$ & $2.16 \mathrm{~b}$ & $2.93 \mathrm{~b}$ & $72.8 \mathrm{~b}$ & $61.4 \mathrm{~b}$ & $69.3 \mathrm{c}$ \\
\hline 2012 & 0 & $2.63 \mathrm{a}$ & $1.46 \mathrm{a}$ & $1.58 \mathrm{a}$ & $60.8 \mathrm{a}$ & $46.0 \mathrm{a}$ & $43.7 \mathrm{a}$ \\
\hline 2013 & 0 & $2.96 \mathrm{a}$ & $1.58 \mathrm{a}$ & $2.23 \mathrm{a}$ & $61.2 \mathrm{a}$ & $47.4 \mathrm{a}$ & $56.8 \mathrm{~b}$ \\
\hline \multirow{4}{*}{2011} & 40 & $3.77 \mathrm{a}$ & $1.97 \mathrm{a}$ & $2.83 \mathrm{a}$ & $73.2 \mathrm{a}$ & $54.8 \mathrm{a}$ & $66.3 \mathrm{a}$ \\
\hline & 60 & $4.12 \mathrm{~b}$ & $3.61 \mathrm{~b}$ & $3.10 \mathrm{~b}$ & $81.6 \mathrm{~b}$ & $94.3 \mathrm{~b}$ & $73.8 \mathrm{~b}$ \\
\hline & 80 & $4.43 \mathrm{~b}$ & $4.14 \mathrm{c}$ & $3.38 \mathrm{c}$ & $83.0 \mathrm{~b}$ & $100.4 \mathrm{c}$ & $76.4 \mathrm{~b}$ \\
\hline & Mean & 4.11 & 3.24 & 3.10 & 79.3 & 83.2 & 72.2 \\
\hline \multirow{4}{*}{2012} & 40 & $2.37 \mathrm{a}$ & $1.87 \mathrm{a}$ & $1.86 \mathrm{a}$ & $54.5 \mathrm{a}$ & $60.1 \mathrm{a}$ & $52.0 \mathrm{a}$ \\
\hline & 60 & $2.95 \mathrm{~b}$ & $2.03 \mathrm{ab}$ & $1.94 \mathrm{a}$ & $70.0 \mathrm{~b}$ & $64.8 \mathrm{~b}$ & $52.8 \mathrm{a}$ \\
\hline & 80 & $3.14 \mathrm{~b}$ & $2.28 \mathrm{~b}$ & $1.91 \mathrm{a}$ & $72.6 \mathrm{~b}$ & $70.5 \mathrm{c}$ & $51.9 \mathrm{a}$ \\
\hline & Mean & 2.82 & 2.06 & 1.90 & 65.7 & 65.2 & 52.2 \\
\hline \multirow{4}{*}{2013} & 40 & $2.84 \mathrm{a}$ & $2.46 \mathrm{a}$ & $2.93 \mathrm{a}$ & $64.8 \mathrm{a}$ & $73.5 \mathrm{a}$ & $74.8 \mathrm{a}$ \\
\hline & 60 & $3.00 \mathrm{a}$ & $2.50 \mathrm{a}$ & $3.19 \mathrm{~b}$ & $69.8 \mathrm{~b}$ & $74.3 \mathrm{a}$ & $81.9 \mathrm{~b}$ \\
\hline & 80 & $2.96 \mathrm{a}$ & $2.65 \mathrm{a}$ & $3.41 \mathrm{c}$ & $67.4 \mathrm{~b}$ & $77.6 \mathrm{~b}$ & $89.1 \mathrm{c}$ \\
\hline & Mean & 2.93 & 2.54 & 3.18 & 67.3 & 75.1 & 81.9 \\
\hline
\end{tabular}

*Values in the same column followed by a different letter are significantly different $(\mathrm{p}<0.05)$

Table 9. Number of grain per ear and thousand grain weight of cereals depending on cereal species and percentage of lupine in mixture

\begin{tabular}{c|c|c|c|c|c|c|c}
\hline \multirow{2}{*}{ Years } & Lupine & \multicolumn{3}{|c|}{ Number of grain per ear (unit) } & \multicolumn{3}{c}{ Wight of 1000 grains (g) } \\
\cline { 3 - 8 } & percentage (\%) & Barley & Wheat & Triticale & Barley & Wheat & Triticale \\
\hline 2011 & 0 & $16.1 \mathrm{a}^{*}$ & $30.4 \mathrm{~b}$ & $33.5 \mathrm{c}$ & $48.2 \mathrm{~b}$ & $35.2 \mathrm{~b}$ & $42.3 \mathrm{c}$ \\
2012 & 0 & $16.6 \mathrm{a}$ & $26.7 \mathrm{a}$ & $24.7 \mathrm{a}$ & $43.2 \mathrm{a}$ & $31.8 \mathrm{a}$ & $36.1 \mathrm{a}$ \\
2013 & 0 & $16.1 \mathrm{a}$ & $27.9 \mathrm{a}$ & $28.4 \mathrm{~b}$ & $48.4 \mathrm{~b}$ & $33.4 \mathrm{ab}$ & $39.3 \mathrm{~b}$ \\
\hline \hline \multirow{4}{*}{2011} & 40 & $17.0 \mathrm{a}$ & $31.1 \mathrm{a}$ & $34.6 \mathrm{a}$ & $52.0 \mathrm{a}$ & $35.6 \mathrm{a}$ & $42.6 \mathrm{a}$ \\
& 60 & $18.1 \mathrm{a}$ & $33.9 \mathrm{~b}$ & $34.2 \mathrm{a}$ & $51.4 \mathrm{a}$ & $38.1 \mathrm{~b}$ & $42.0 \mathrm{a}$ \\
& 80 & $17.1 \mathrm{a}$ & $32.6 \mathrm{ab}$ & $35.5 \mathrm{a}$ & $52.8 \mathrm{a}$ & $40.8 \mathrm{~b}$ & $44.3 \mathrm{~b}$ \\
\cline { 2 - 8 } & Mean & 17.4 & 32.5 & 34.8 & 52.1 & 38.2 & 42.9 \\
\hline \multirow{4}{*}{2012} & 40 & $16.0 \mathrm{a}$ & $30.1 \mathrm{a}$ & $28.9 \mathrm{a}$ & $43.4 \mathrm{a}$ & $31.1 \mathrm{a}$ & $35.8 \mathrm{a}$ \\
& 60 & $16.8 \mathrm{a}$ & $31.0 \mathrm{a}$ & $28.7 \mathrm{a}$ & $42.2 \mathrm{a}$ & $31.4 \mathrm{a}$ & $36.7 \mathrm{a}$ \\
& 80 & $16.5 \mathrm{a}$ & $32.4 \mathrm{a}$ & $27.5 \mathrm{a}$ & $43.3 \mathrm{a}$ & $32.4 \mathrm{a}$ & $36.8 \mathrm{a}$ \\
\hline \multirow{4}{*}{2013} & Mean & 16.4 & 31.2 & 28.4 & 42.9 & 31.5 & 36.4 \\
\cline { 2 - 8 } & 40 & $17.1 \mathrm{~b}$ & $31.0 \mathrm{a}$ & $29.7 \mathrm{a}$ & $44.9 \mathrm{a}$ & $33.4 \mathrm{a}$ & $39.1 \mathrm{a}$ \\
& 60 & $16.9 \mathrm{~b}$ & $32.3 \mathrm{a}$ & $31.2 \mathrm{a}$ & $43.1 \mathrm{a}$ & $33.6 \mathrm{a}$ & $39.0 \mathrm{a}$ \\
& 80 & $15.2 \mathrm{a}$ & $33.3 \mathrm{a}$ & $33.4 \mathrm{~b}$ & $43.9 \mathrm{a}$ & $34.1 \mathrm{a}$ & $38.3 \mathrm{a}$ \\
\hline
\end{tabular}

*Values in the same column followed by a different letter are significantly different $(\mathrm{p}<0.05)$ 
Table 10. The height of cereals culm in mixture with lupine and number of shoot production

\begin{tabular}{c|c|c|c|c|c|c|c}
\hline \multirow{2}{*}{ Years } & Lupine & \multicolumn{3}{|c|}{ Height of cereals (cm) } & \multicolumn{3}{c}{ Number of shoot production (unit) } \\
\cline { 3 - 8 } & percentage (\%) & Barley & Wheat & Triticale & Barley & Wheat & Triticale \\
\hline 2011 & 0 & 57 & 69 & 75 & 4.55 & 1.95 & 2.15 \\
2012 & 0 & 58 & 64 & 75 & 3.67 & 1.73 & 1.87 \\
2013 & 0 & 61 & 64 & 78 & 3.80 & 1.70 & 2.00 \\
\hline \hline \multirow{5}{*}{2011} & 40 & 57 & 68 & 77 & 4.1 & 1.70 & 1.87 \\
& 60 & 57 & 70 & 76 & 4.5 & 1.90 & 1.90 \\
& 80 & 58 & 70 & 75 & 4.6 & 1.90 & 2.10 \\
\cline { 2 - 8 } & Mean & $57 \mathrm{a}$ & $69 \mathrm{~b}$ & $76 \mathrm{~b}$ & $4.40 \mathrm{~b}$ & $1.83 \mathrm{a}$ & $1.95 \mathrm{a}$ \\
\hline \multirow{5}{*}{2012} & 40 & 57 & 62 & 76 & 3.40 & 2.00 & 1.80 \\
& 60 & 59 & 63 & 77 & 4.17 & 2.09 & 1.84 \\
& 80 & 61 & 62 & 74 & 4.37 & 2.17 & 1.89 \\
\hline \multirow{4}{*}{2013} & Mean & $59 \mathrm{a}$ & $62 \mathrm{a}$ & $76 \mathrm{~b}$ & $3.98 \mathrm{~b}$ & $2.09 \mathrm{a}$ & $1.84 \mathrm{a}$ \\
\hline & 40 & 71 & 69 & 78 & 3.80 & 2.37 & 2.52 \\
& 60 & 72 & 69 & 79 & 4.12 & 2.30 & 2.63 \\
& 80 & 73 & 70 & 80 & 4.43 & 2.33 & 2.67 \\
\hline & Mean & $72 \mathrm{a}$ & $69 \mathrm{a}$ & $79 \mathrm{~b}$ & $4.12 \mathrm{~b}$ & $2.33 \mathrm{a}$ & $2.61 \mathrm{a}$ \\
\hline
\end{tabular}

*Values in the same rows followed by a different letter are significantly different $(\mathrm{p}<0.05)$

The grain of spring cereal grown in mixtures with yellow lupine contained more total protein than when it is grown in pure stands (Table 11).

Table 11. Contents of total protein (\%) in seeds depending on cereal species and percentage of lupine in mixture

\begin{tabular}{c|c|c|c|c|c|c|c|c}
\hline \multirow{2}{*}{ Specification } & \multicolumn{3}{|c|}{ Cereal } & \multirow{2}{*}{ Mean } & \multicolumn{3}{|c|}{ Lupine } & \multirow{2}{*}{ Mean } \\
\cline { 2 - 5 } & $\mathbf{2 0 1 1}$ & $\mathbf{2 0 1 2}$ & $\mathbf{2 0 1 3}$ & & $\mathbf{2 0 1 1}$ & $\mathbf{2 0 1 2}$ & $\mathbf{2 0 1 3}$ & \\
\hline Lupine & - & - & - & - & 36.8 & 40.8 & 43.4 & 40.3 \\
\hline Barley - PS* & 11.3 & 11.6 & 9.9 & 11.0 & - & - & - & - \\
Mixtures & & & & & & & & \\
$40 \%$ & 11.9 & 12.5 & 11.6 & 12.0 & 36.6 & 40.5 & 43.4 & 40.2 \\
$60 \%$ & 11.8 & 12.4 & 11.8 & 12.0 & 36.9 & 40.2 & 43.6 & 40.3 \\
$80 \%$ & 13.5 & 13.9 & 12.2 & 13.2 & 36.8 & 39.7 & 44.4 & 40.3 \\
\hline Wheat-PS & 13.2 & 13.1 & 13.2 & 13.2 & - & - & - & - \\
Mixtures & & & & & & & & \\
$40 \%$ & 13.6 & 13.7 & 13.4 & 13.6 & 36.9 & 40.9 & 43.1 & 40.3 \\
$60 \%$ & 14.1 & 14.1 & 13.5 & 13.9 & 36.1 & 40.1 & 43.5 & 39.9 \\
$80 \%$ & 14.2 & 14.6 & 13.5 & 14.1 & 36.2 & 40.2 & 43.8 & 40.1 \\
\hline Triticale-PS & 12.8 & 13.2 & 12.7 & 12.9 & - & - & - & - \\
Mixtures & & & & & & & & \\
$40 \%$ & 13.4 & 14.1 & 13.3 & 13.6 & 36.2 & 41.8 & 43.5 & 40.5 \\
$60 \%$ & 13.8 & 14.2 & 14.0 & 14.0 & 36.2 & 41.2 & 43.5 & 40.3 \\
$80 \%$ & 13.4 & 13.9 & 14.2 & 13.8 & 36.1 & 41.6 & 43.7 & 40.5 \\
\hline
\end{tabular}

*PS - pure sowing 
In the year with lower rainfall (2012), cereal grains accumulated slightly more protein than in other years. There was also an increase in the amount of this component in cereal grains in the mixtures with a higher percentage of lupine. Grains of wheat and triticale contained a similar amount of protein, but it was larger than in grains of barley. Cereals only slightly affected the accumulation of total protein by lupine seeds (a similar content); weather conditions were more important. In 2011 lupine seeds contained much less protein. The grains of cereals, grown in mixtures with lupine, contained more crude fibre than the ones from cereals grown in pure stand, while cereals did not affect the accumulation of this component by lupine seeds (Table 12). Cereals generally accumulated more crude fibre in 2013, while in the years of 2011 and 2012 there was a tendency to store more fibre in cereal grains with a higher percentage of yellow lupine in mixture. Legume seeds, in turn, contained significantly less crude fibre in dry year of 2012 compared to other years of vegetation.

Table 12. Concentrations of crude fibre (\%) in seeds depending on cereal species and percentage of lupine in mixture

\begin{tabular}{c|c|c|c|c|c|c|c|c}
\hline \multirow{2}{*}{ Specification } & \multicolumn{3}{|c|}{ Cereal } & Mean & \multicolumn{3}{|c|}{ Lupine } & Mean \\
\cline { 2 - 9 } & $\mathbf{2 0 1 1}$ & $\mathbf{2 0 1 2}$ & $\mathbf{2 0 1 3}$ & & $\mathbf{2 0 1 1}$ & $\mathbf{2 0 1 2}$ & $\mathbf{2 0 1 3}$ & \\
\hline Lupine & - & - & - & - & 12.9 & 12.4 & 12.8 & 12.7 \\
\hline Barley-PS* & 3.57 & 3.52 & 4.67 & 3.92 & - & - & - & - \\
Mixtures & & & & & & & & \\
$40 \%$ & 3.47 & 3.80 & 4.80 & 4.02 & 13.4 & 12.3 & 13.1 & 12.9 \\
$60 \%$ & 3.61 & 3.87 & 4.60 & 4.03 & 13.3 & 12.1 & 12.3 & 12.6 \\
$80 \%$ & 3.55 & 3.96 & 4.75 & 4.09 & 12.4 & 12.2 & 13.2 & 12.6 \\
\hline Wheat-PS & 2.25 & 2.25 & 2.52 & 2.34 & - & - & - & - \\
Mixtures & & & & & & & & \\
$40 \%$ & 2.22 & 2.22 & 2.74 & 2.39 & 13.2 & 12.4 & 13.4 & 13.0 \\
$60 \%$ & 2.34 & 2.34 & 2.70 & 2.46 & 13.0 & 12.2 & 13.2 & 12.8 \\
$80 \%$ & 2.38 & 2.58 & 2.64 & 2.53 & 12.8 & 12.8 & 13.1 & 12.9 \\
\hline Triticale-PS & 2.19 & 2.20 & 2.59 & 2.33 & - & - & - & - \\
Mixtures & & & & & & & & \\
$40 \%$ & 2.39 & 2.50 & 2.74 & 2.54 & 13.1 & 12.5 & 12.8 & 12.8 \\
$60 \%$ & 2.31 & 2.50 & 2.80 & 2.54 & 12.9 & 12.3 & 13.2 & 12.8 \\
$80 \%$ & 2.48 & 2.45 & 2.77 & 2.57 & 13.0 & 12.2 & 13.3 & 12.8 \\
\hline
\end{tabular}

*PS - pure sowing

\section{Conclusions}

1. Yields of the mixtures of spring cereals with yellow lupine, especially with the $80 \%$ share of legumes, were lower than that of the cereals grown in pure stands.

2. The yellow lupine-wheat mixture yielded better than that with barley and triticale, regardless of the percentage of components.

3. Increasing the percentage of lupine seeds at sowing resulted in a significant decrease in the level of mixture yields, regardless of the species of cereal. 
4. The percentage of lupine seeds in mixture yields was much lower than at the sowing, regardless of the species of cereal, while its average percentage in the yield of the mixture with wheat was much larger than with barley and triticale.

5. Yellow lupine grown in a mixture set a lower number of pods, seeds per pod and per plant, and produced a lower seeds weight compared to the plants grown in pure stands.

6. Growing yellow lupine in a mixture with spring cereals positively affected morphological characteristics of cereals. Increasing the percentage of legume seeds at the sowing caused a better tillering of cereals and producing a higher number and weight of grains per plant.

7. The grain of cereals grown in mixtures with lupine had a higher content of total protein and crude fibre than when they were grown in pure stands. There was no significant impact of the cereal plant on the content of total protein and crude fibre in legume seeds. Weather conditions, especially humidity had a greater impact on the chemical composition of legume seeds.

8. Future research aimed at selection of compatible species and varieties, appropriate plant geometry and temporal arrangement of the various components of mixture under different locations and soil conditions could enhance adoption of legume-cereal mixtures in Europe.

Acknowledgements. This work was supported by the Ministry of Agriculture and Rural Development of Poland under multi-annual program "Improving domestic sources of vegetable protein, their production, trading and use in animal feed".

\section{REFERENCES}

[1] Büyükburç, U., Karadağ, Y. (2002): The amount of NO-N transferred to soil by legumes, forage and seed yield, and the forage quality of annual legume/triticale mixtures. Turkish Journal of Agriculture and Forestry 26(5): 281-288.

[2] Corre-Hellou, G., Dibet, A., Hauggaard-Nielsen, H., Crozat, Y., Gooding, M., Ambus, P., Dahlmann, C., Von Fragstein, P., Pristeri, A., Montie, M., Jensen, E. S. (2011): The competitive ability of pea-barley intercrops against weeds and the interactions with crop productivity and soil N availability. - Field Crops Research 122(3): 264-272.

[3] Cremer, N. G., Bennett, M. A., Stinner, B. R., Cardina, J., Regnier, E. E. (1996): Mechanism of weed suppression in cover crop-based production systems. - Horticultural Science 31(3): 410-413.

[4] Doré, T., Makowski, D., Malézieux, E., Munier-Jolain, N., Tchamitchian, M., Tittonell, P. (2011): Facing up to the paradigm of ecological intensification in agronomy: Revisiting methods, concepts and knowledge. - European Journal of Agronomy 34(4): 197-210.

[5] Gałęzewski, L. (2006): Response of yellow lupine on soil moisture in sole crop and in intercrop with oat. - Roczniki AR Poznań 66: 55-65.

[6] Hassen, A., Talore, D. G., Tesfamariam, E. H., Friend, M. A., Mpanza, T. D. E. (2017): Potential use of forage-legume intercropping technologies to adopt to climate-change impacts on mixed crop-livestock systems in Africa: a review. - Regional Environmental Change 17(6): 1713-1724. DOI: 10.1007/s10113-017-1131-7.

[7] Hauggaard-Nielsen, H., Jensen, E. S. (2004): Weed management in grain legumes using an intercropping approach. - In: Jacobsen, S.-E., Jensen, C. R., Porter, J. R. (eds.) Book of Proceedings. VIII ESA Congress, European Agriculture in a Global Context, 11-15 
July, 2004, Copenhagen, Denmark, pp. 605-606. Royal Veterinary \& Agricultural University, Taastrup.

[8] Hauggaard-Nielsen, H., Jřrnsgaard, B., Kinane, J., Jensen, E. S. (2008): Grain legumecereal intercropping: the practical application of diversity, competition and facilitation in arable and organic cropping systems. - Renewable Agriculture and Food Systems 23: 312.

[9] Jaranowski, J. K. (1997): New genotype of Pisum sp. derived from hybridization of mutants and cultivates. - Genetica Polonica 18(4): 337-355.

[10] Johnston, H. W., Sanderson, J. B., Macleod, J. A. (1978): Cropping mixtures of field peas and cereals in Prince Edward Island. - Canadian Journal of Plant Science 58: 421-426.

[11] Kotwica, K., Rudnicki, F. (2003): Mixtures of spring cereals with legumes on light soil. Zeszyty Problemowe Postępów Nauk Rolniczych 495: 163-170.

[12] Kotwica, K., Rudnicki, F. (2004): Production effects of growing spring cereal and cerealand-legume mixtures on good rye complex soil. - Acta Scientiarum Polonorum Sectio Agriculture 3(1): 149-156.

[13] Księżak, J. (2006): Evaluation yields of mixtures pea with spring wheat depending on nitrogen doses. - Fragmenta Agronomica 3: 80-93.

[14] Księżak, J., Magnuszewska, K. (1999): Yielding of pea and cereals mixtures in selected country region. - Fragmenta Agronomica 3: 89-96.

[15] Księżak, J., Staniak, M. (2013): Evaluation of mixtures of blue lupine (Lupinus angustifolius L.) with spring cereals grown for seeds in organic farming system. - Joural of Food Agriculture and Environment 11(3/4): 1670-1676.

[16] Lithourgidis, A. S., Vasilakoglou, I. B., Dhima, K. V., Dordas, C. A., Yiakoulaki, M. D. (2006): Forage yield and quality of common vetch mixtures with oat and triticale in two seeding ratios. - Field Crops Research 99(2/3): 106-113.

[17] Niggli, U., Slab, A., Schmid, O., Halberg, N., Schlüter, M. (2008): Vision for an Organic Food and Farming Research Agenda to 2025. Report. - IFOAM EU Group, Brussels and ISOFAR, Bonn.

[18] Podleśny, J., Podleśna, A. (2010): Effect of drought stress on blue lupine yield grown in pure stand and in mixture with barley. - Proceedings: The Economic Importance and Biology of Crop Yields Mixed, 3-5 March, 2010, Poznań, Poland, pp. 68-69.

[19] Pozdísek, J., Henriksen, B., Løes, A. K., Ponizil, A. (2011): Utilizing legume-cereal intercropping for increasing self-sufficiency on organic farms in feed for monogastric animals. - Agronomy Research 9(1/2): 343-356.

[20] Rojek, S. (1989): Water Requirements of Papilionaceous Plants.. In: Dzieżyc, I. (ed.) Water Requirements of Crop. - PWN, Warsaw, Poland.

[21] Rudnicki, F., Gałęzewski, L. (2007a): Response of oat and yellow lupine to their various participation in intercropping and their productivity in intercrops, part I. Reaction of oat and yellow lupine to intercropping. - Zeszyty Problemowe Postepów Nauk Rolniczych 516: 161-170.

[22] Rudnicki, F., Gałęzewski, L. (2007b): Response of oat and yellow lupine to their various participation in intercropping and their productivity in intercrops, part II. Yielding of intercrops. - Zeszyty Problemowe Postepów Nauk Rolniczych 516: 171-179.

[23] Rudnicki, F., Kotwica, K. (2006): Productivity of lupine-cereal intercrops on rye very good soil complex. - Proceedings: The Economic Importance and Biology of Crop Yields Mixed, 11-12 May, 2006, Poznań, Poland, pp. 62-63.

[24] Rudnicki, F., Kotwica, K. (2007): Competitive interactions between spring cereals and lupin in mixtures and mixture growing production effects on very good rye complex soil. - Fragmenta Agronomica 4(96): 145-152.

[25] Rudnicki, F., Wenda-Piesik, A. (2007): Productivity od pea-cereal intercrops on good rye soil complex). - Zeszyty Problemowe Postępów Nauk Rolniczych 516: 181-193. 
[26] Staniak, M., Księżak, J., Bojarszczuk, J. (2012): Estimation of productivity and nutritive value of pea-barley mixtures in organic farming. - Journal of Food Agriculture and Environment 10(2): 318-323.

[27] Staniak, M., Księżak, J., Bojarszczuk, J. (2014): Mixtures of Legumes with Cereals as a Source of Feed for Animals. - In: Pilipavicius, V. (ed.) Organic Agriculture towards Sustainability. INTECH, Rijeka, Croatia.

[28] Szczukowski, S. (1989): Yields and quality of field pea reproduction in mixtures with cereals and in pure cultures. - Acta Academiae Agricultutae sectio Technicae 47: 3-41.

[29] Tofinga, M. T., Snaydon, R. W. (1992): The root of cereals and peas when grown in pure stands and mixtures. - Plant and Soil 142: 281-285.

[30] Watson, C. A., Atkinson, D., Gosling, P., Jackson, L. R., Rayns, F. W. (2002): Managing soil fertility in organic farming system. - Soil Use and Management 18: 239-247. 